\title{
CTGF wt Allele
}

National Cancer Institute

\section{Source}

National Cancer Institute. CT GF wt Allele. NCI Thesaurus. Code C62458.

Human CT GF wild-type allele is located in the vicinity of $6 q 23.1$ and is approximately $3 \mathrm{~kb}$ in length. This allele, which encodes connective tissue growth factor protein, is involved in mitogen stimulation and cellular growth signal transduction through the T GFbeta/Smad signaling pathway. The stimulation appears to be regulated by growth factors or specific oncogenes. 